\title{
Finanziell unabhängig nach einem Unfall?
}

\section{Sind Sie sicher?}

$\square$ Ich will finanziell unabhängig sein und möchte mehr über die FMH Insurance Services Einzelunfallversicherung wissen.

$\square$ Ich möchte mich beraten lassen. Bitte rufen Sie mich an.

$\square$ Ich interessiere mich für eine umfassende Vorsorgeberatung.

\section{Vorname/Name}

Adresse

PLZ/Ort

Geburtsdatum

Telefon Privat/Geschäft

Beste Zeit für einen Anruf

E-Mail-Adresse

G̈FMH INSURANCE

Roth Gygax \& Partner AG = Koordinationsstelle Moosstrasse 2 - 3073 Gümligen

Telefon 0319595000 Fax 0319595010

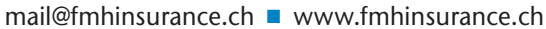

